$\mathrm{Oz}$

Volume 9

Article 20

$1-1-1987$

\title{
The 1986 Tile Competition: a Culinary Institute, Plazza d'Italia, New Orleans
}

Joseph Biondo

Matt Knox

John Low

See next page for additional authors

Follow this and additional works at: https://newprairiepress.org/oz

(c) (i) $\Theta \Theta$

This work is licensed under a Creative Commons Attribution-Noncommercial-No Derivative Works 4.0 License.

\section{Recommended Citation}

Biondo, Joseph; Knox, Matt; Low, John; and Hung, Tan Tee (1987) "The 1986 Tile Competition: a Culinary Institute, Plazza d'Italia, New Orleans," Oz: Vol. 9. https://doi.org/10.4148/2378-5853.1149

This Article is brought to you for free and open access by New Prairie Press. It has been accepted for inclusion in Oz by an authorized administrator of New Prairie Press. For more information, please contact cads@k-state.edu. 


\section{The 1986 Tile Competition: a Culinary Institute, Plazza d'Italia, New Orleans}

Authors

Joseph Biondo, Matt Knox, John Low, and Tan Tee Hung 


\section{Tile Competition}

A Culinary Institute, Plazza d'Italia, New Orleans

\section{Critic: Amos Chang}

Joseph Biondo

Matt Knox

John Low

Tan Tee Hung

"I remembered that the architectural orders were Italian, with a little help from the Greeks, and so we thought we could put Tuscan Doric, Ionic and Cortinthian columns over the fountain, but they overshadowed it, obliterating the shape of Italy. So instead we added a 'Delicatessen Order' that we thought could resemble sausages hanging in a shop window, thus illustrating its transalpine location. But now I think there is going to be an Italian restaurant and no sausages ... there was a little bit of money left over so we thought we would bang up a temple out front to show that our piazza was behind it. There was enough money too to make a campanile beside the temple to show off our existence and to make more patterns with the verticals of the skyscraper behind. Someday there will be shops around it, like Ghirardelli Square, but for the moment, it is just sitting by itself and a little lonesome."

Charles Moore

The project selected for the Fall 1986 Tile Competition was a culinary institute for 100 students located on a site adjacent to the Piazza d'Italia in New Orleans. The plaza, completed in the 70 late 1970s, was a design collaboration between Charles Moore and Perez Architects. The Piazza d'Italia has evoked a myriad of architectural criticism and interest, but has failed to propagate the area into a viable center.

The essence of the design exercise was to manipulate space and form in response to a specifically strong contextual element and concurrently address the urban morphology of the area concluding in a renewed and vivid urban vitality for the Piazza d'Italia.

A more specific analysis of the problem showed the inherent need to present a solution capable of interceding at two levels: First, defined as a solid, the culinary institute must be able to engage with or be engaged by the adjacent void of the Piazza; and, secondly, it must present itself either as figure or ground depending on the desired or specific relationship to the Piazza.

The design solutions presented evolved out of a dialectic interaction with the rational conceptions of the implicit and explicit reality of the context - the goal being to incite a synthesis between the conflicts, emerging with a unifying expression of what is true and valuable in each. The design intention - rather than being an insipid patronage to the Piazza, allowing one object in the collective scheme to dominate - should move through complacency in a dynamic negation of the obvious polarization between the institute and the Piazza d'Italia.

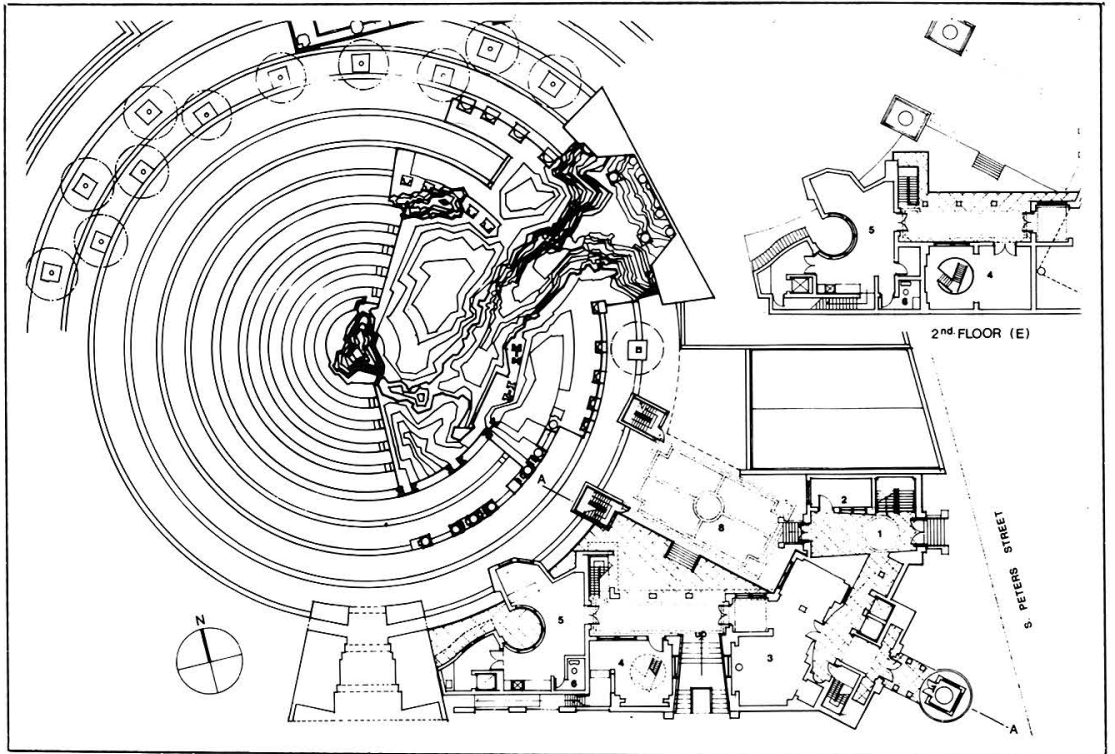

First floor plan

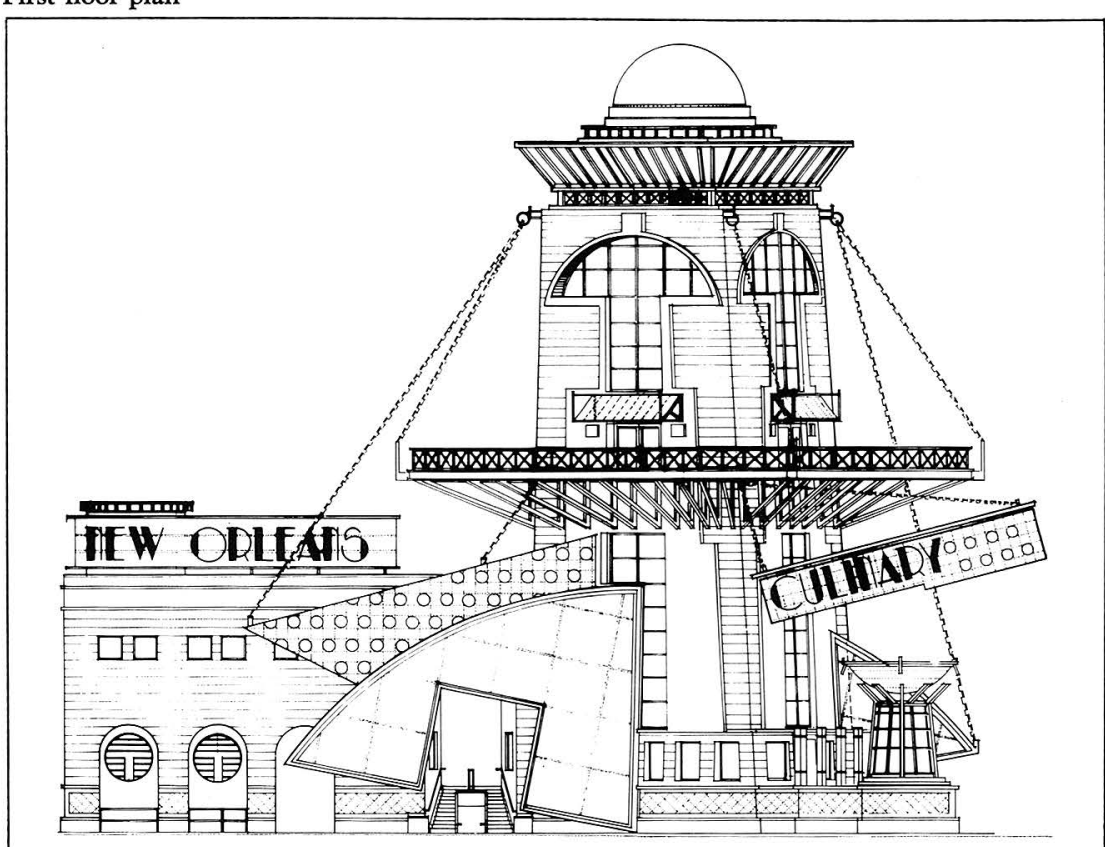

John Low - Lafayette Street elevation 


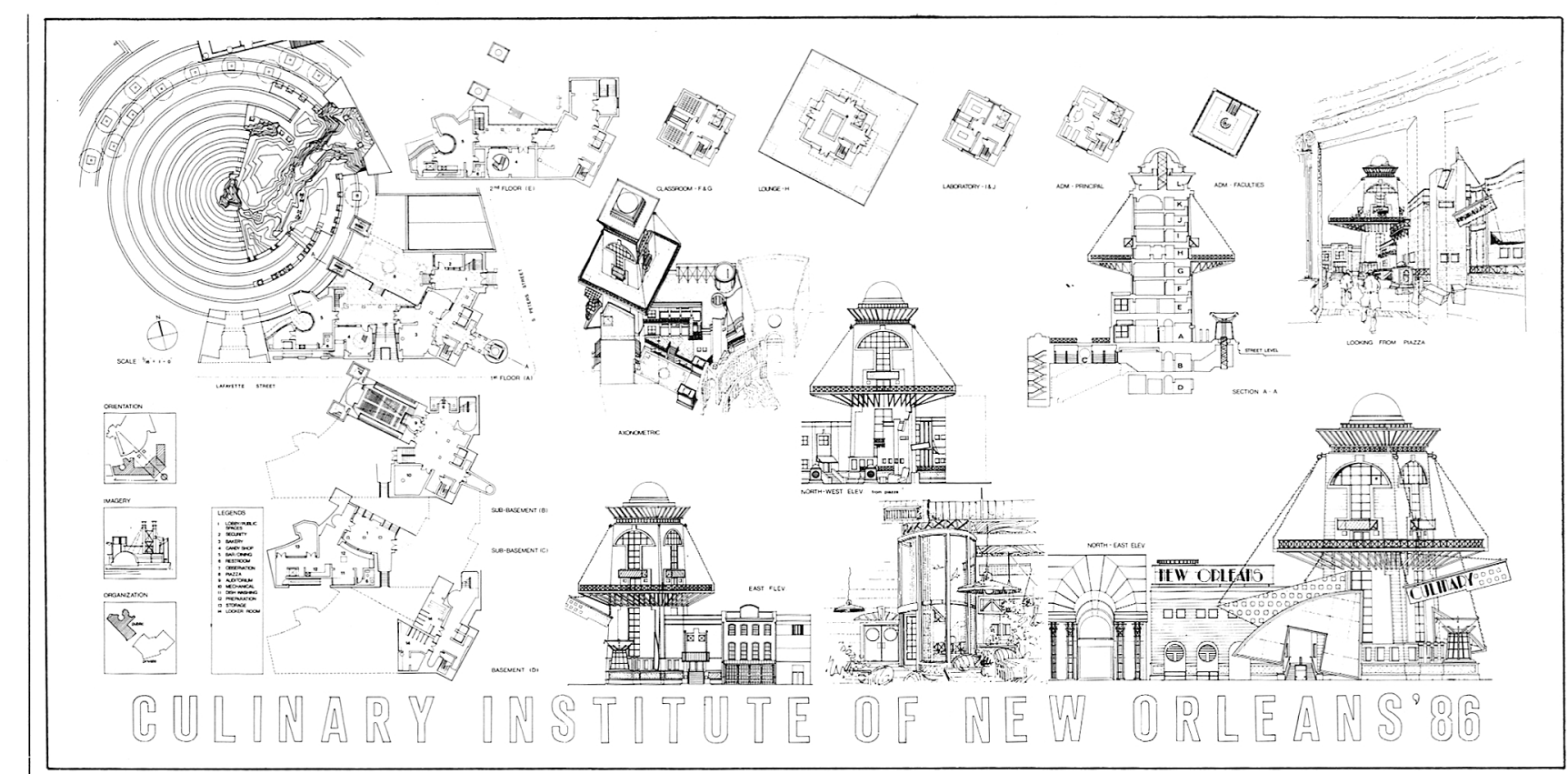

John Low

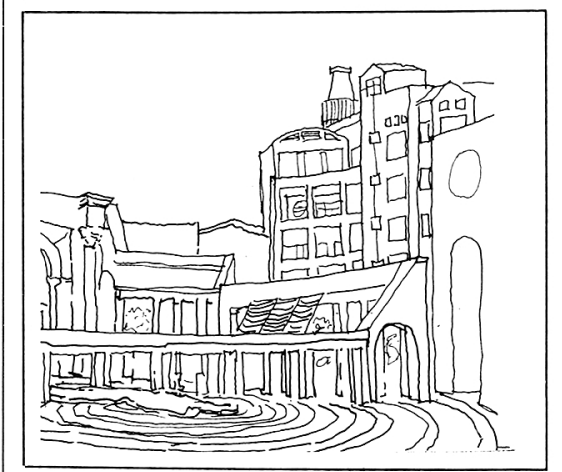

Piazza View
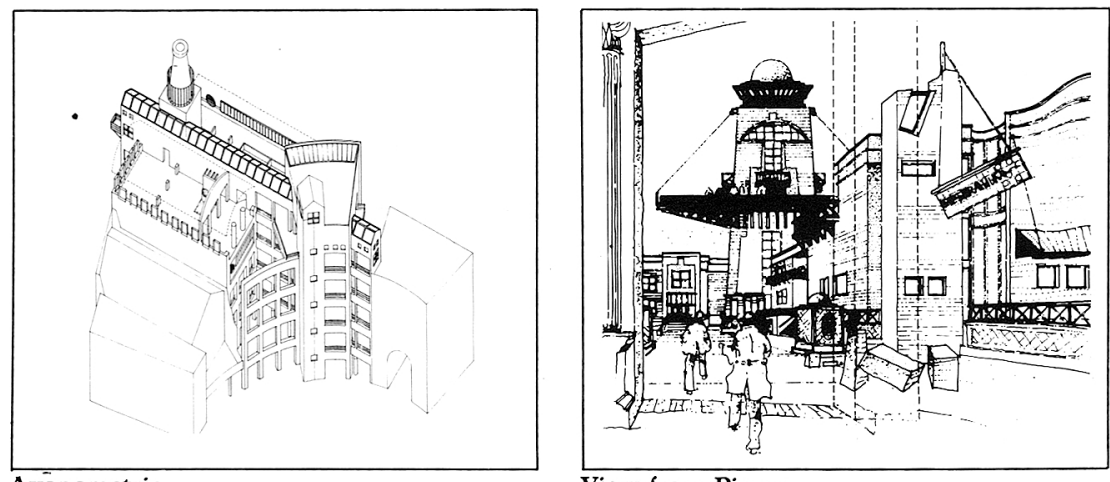

Piaza View

Axonometric

View from Piazza
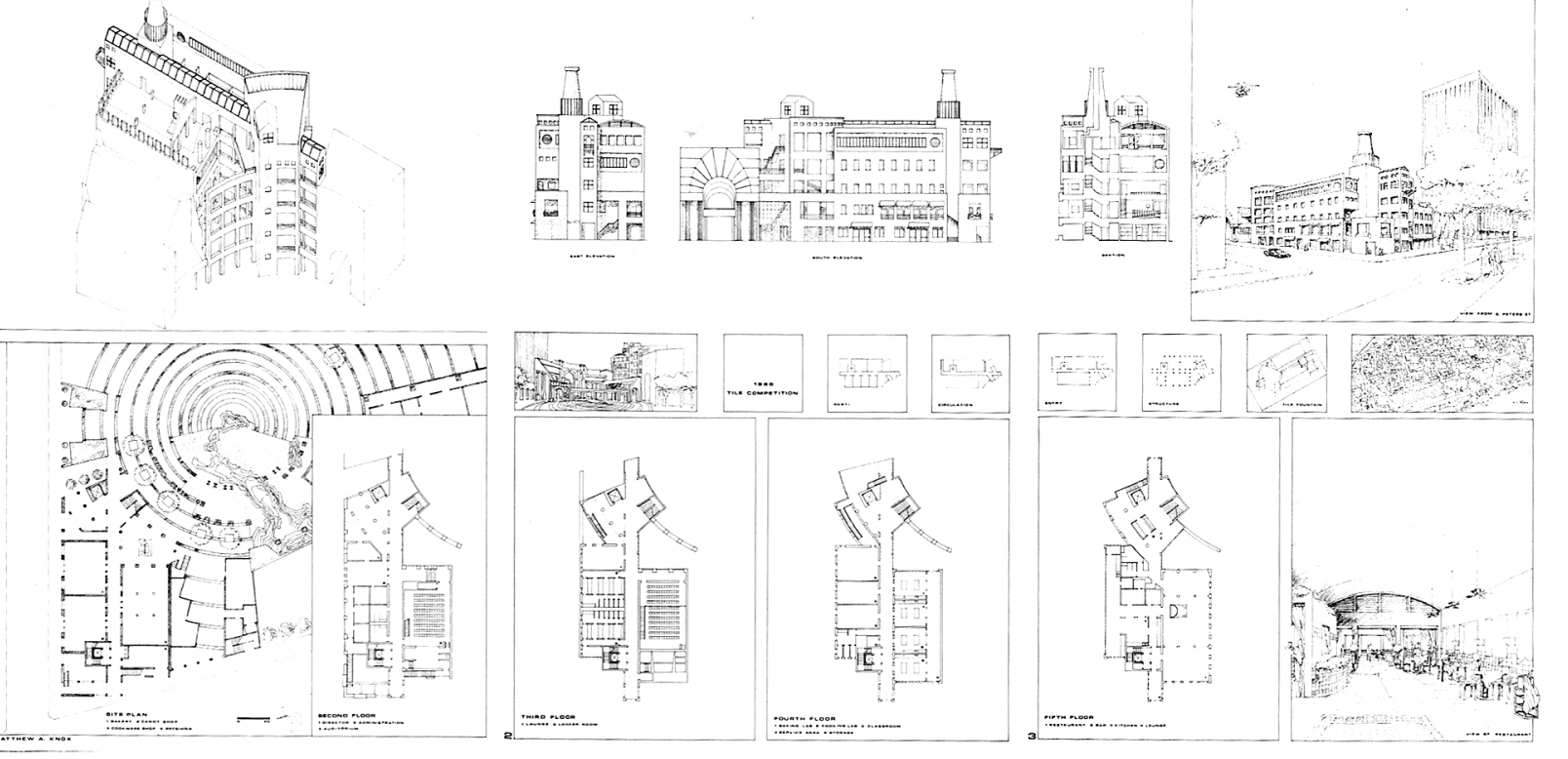

Matt Knox

$=$

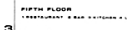
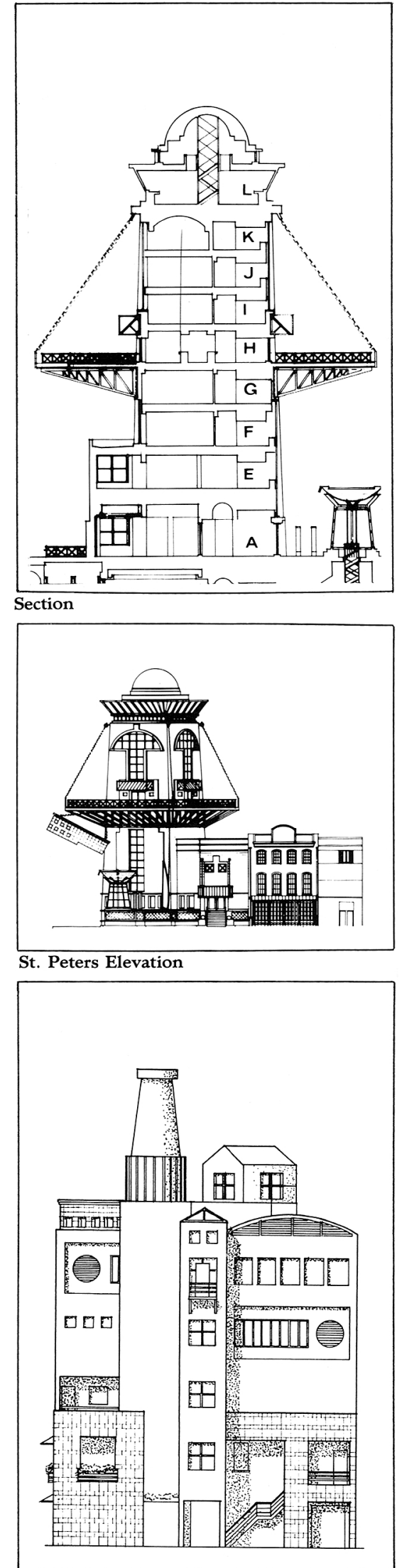

St. Peters Elevation 

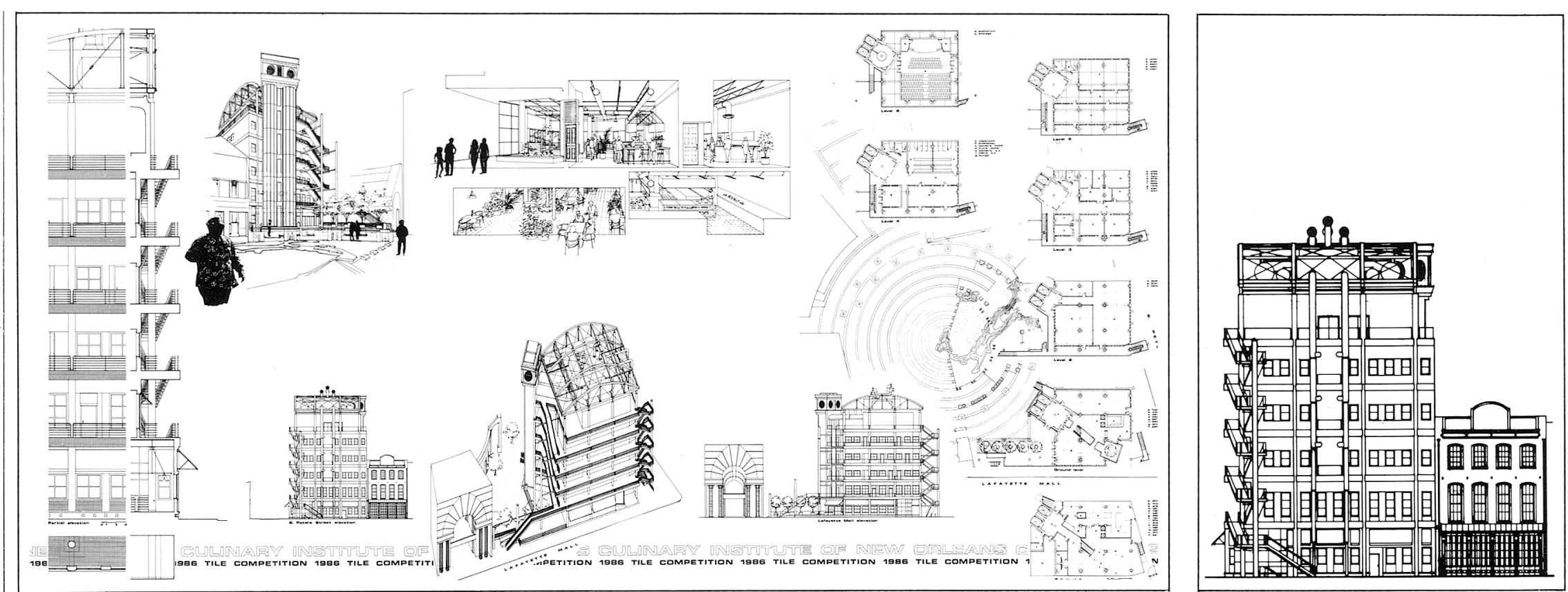

Tan Tee Hung

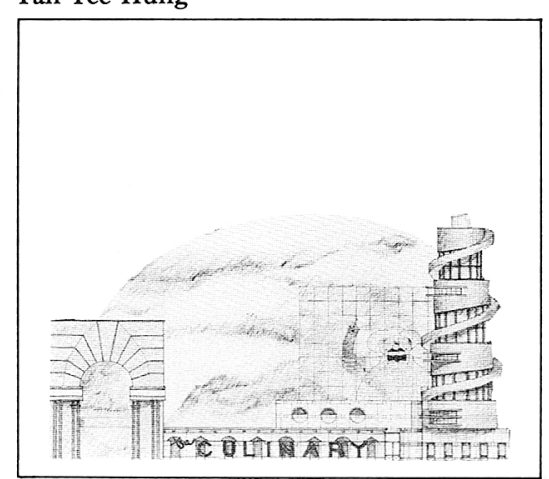

Lafayette Street elevation

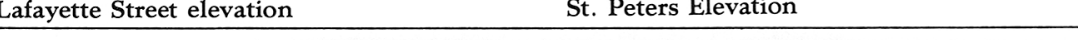

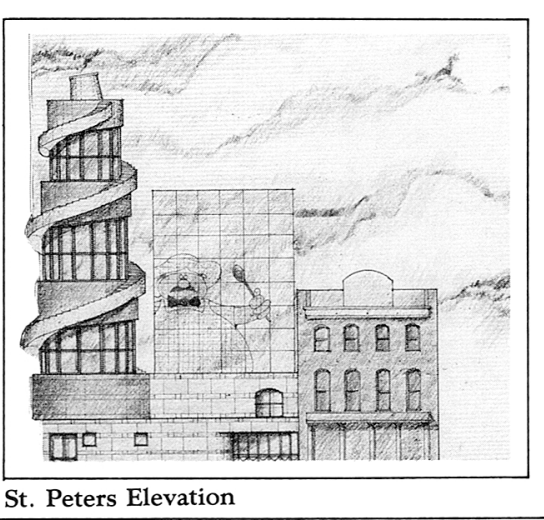

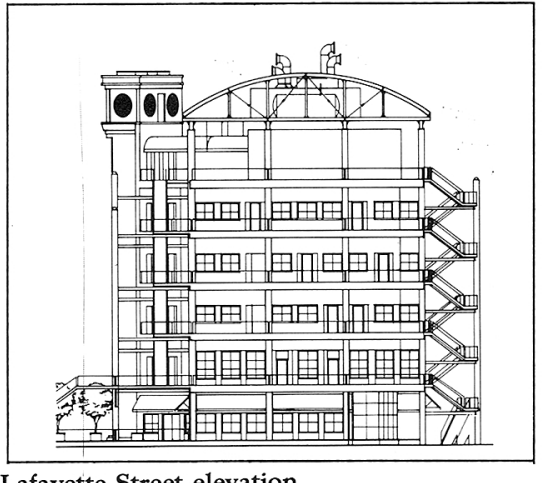

Lafayette Street elevation

St. Peters Elevation

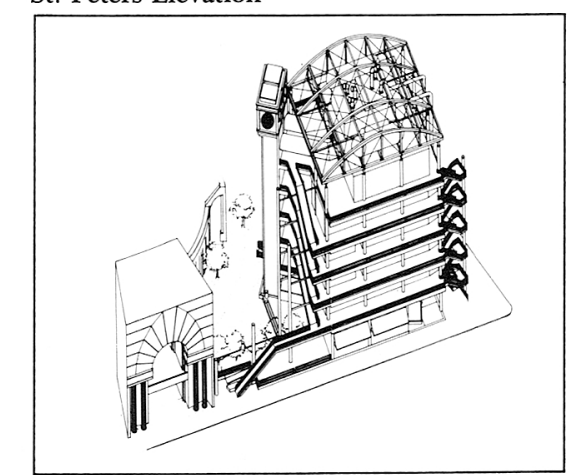

Axonometric

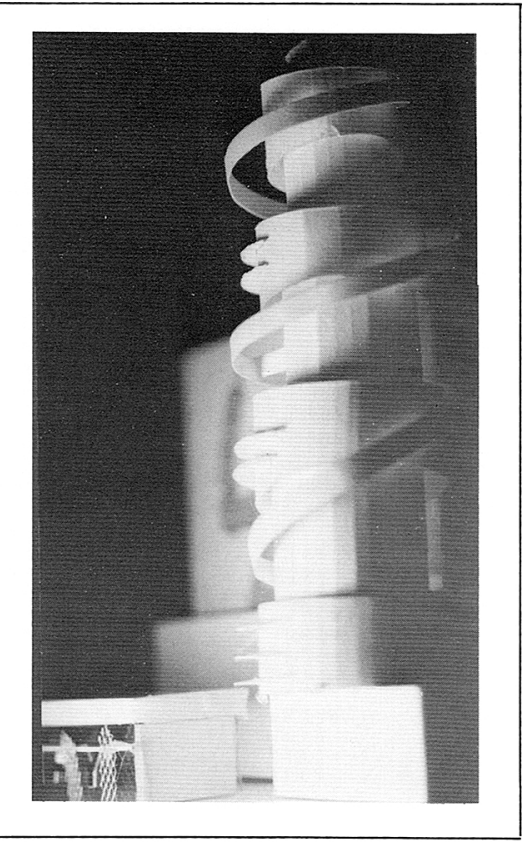

Study model
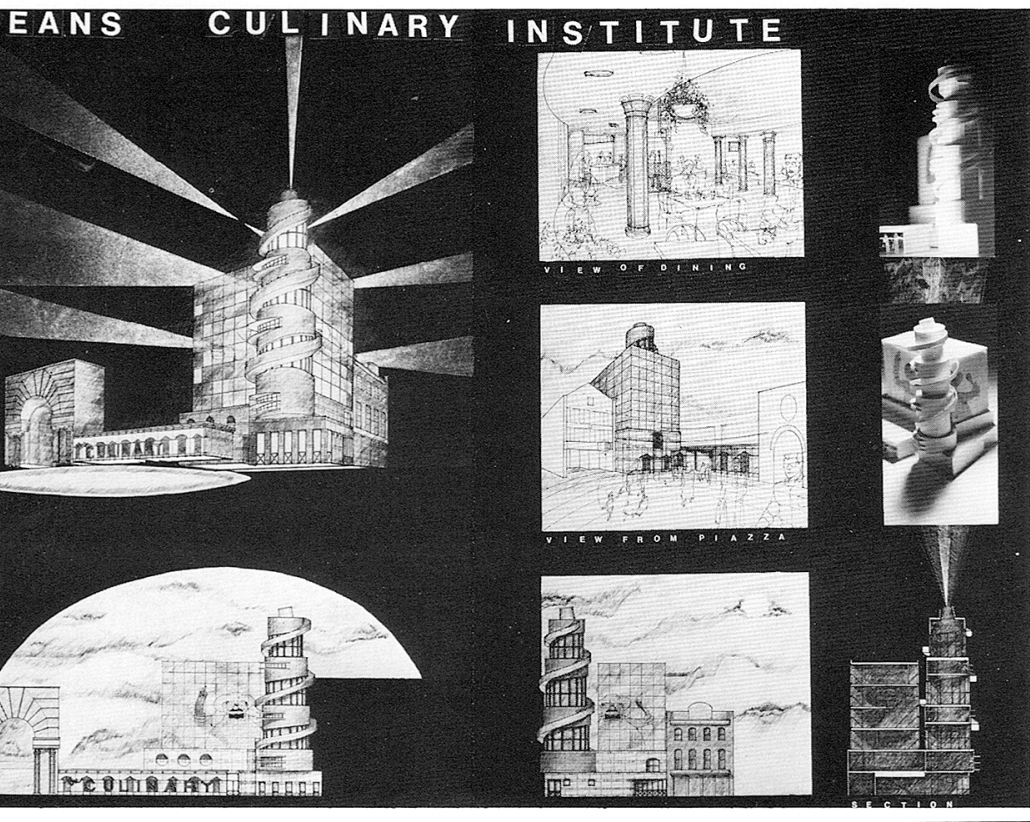

2.
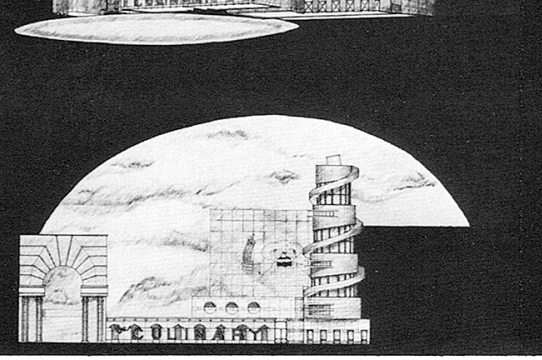

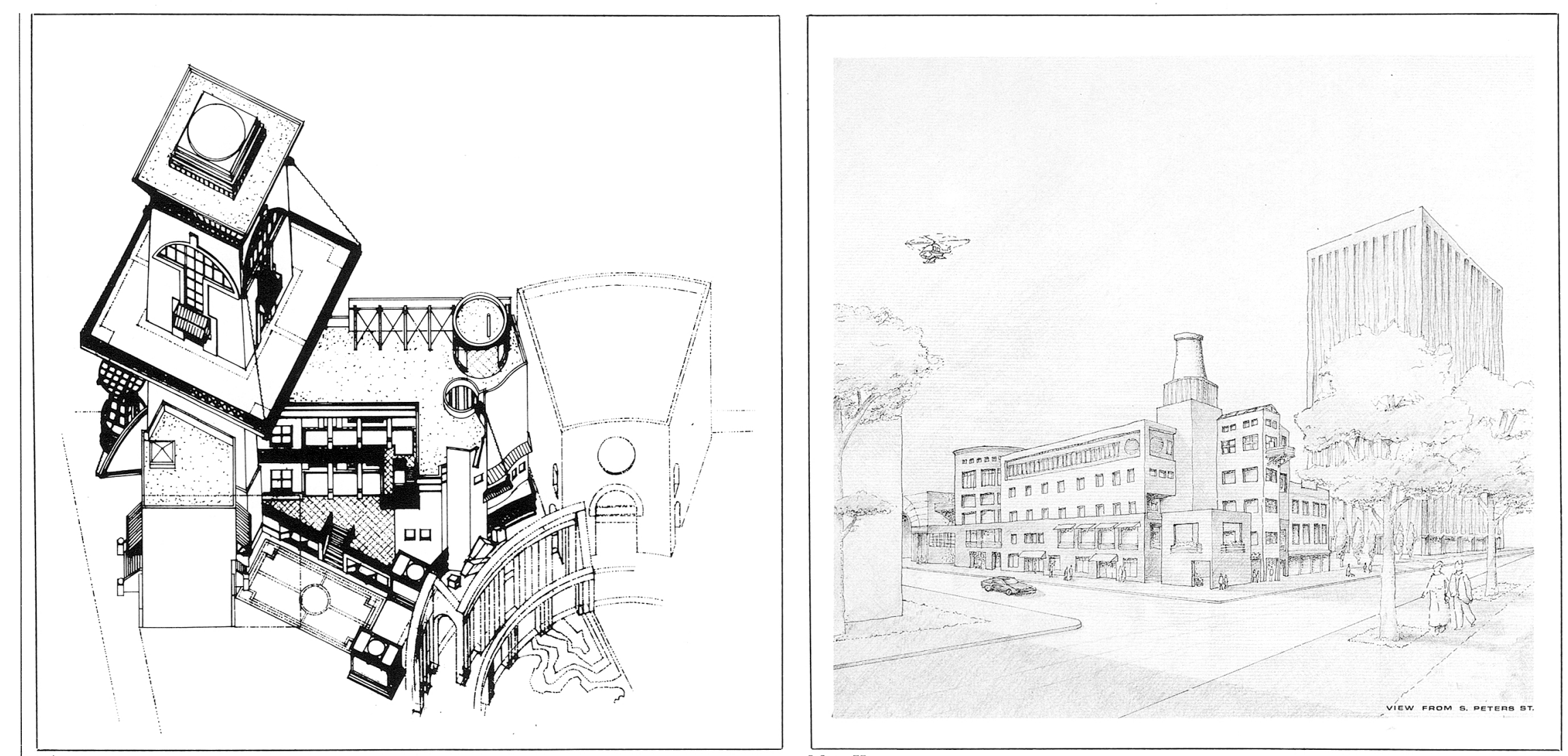

John Low

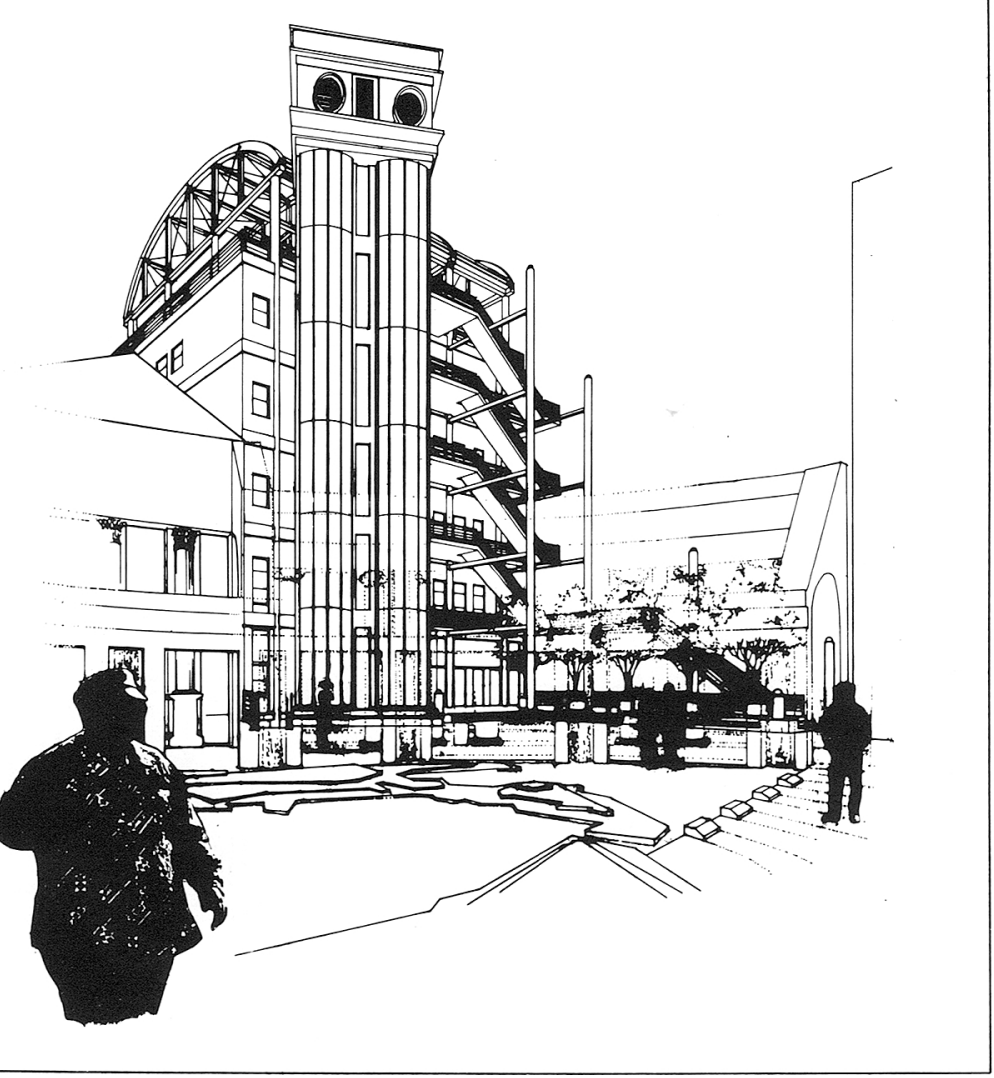

Tan Tee Hung

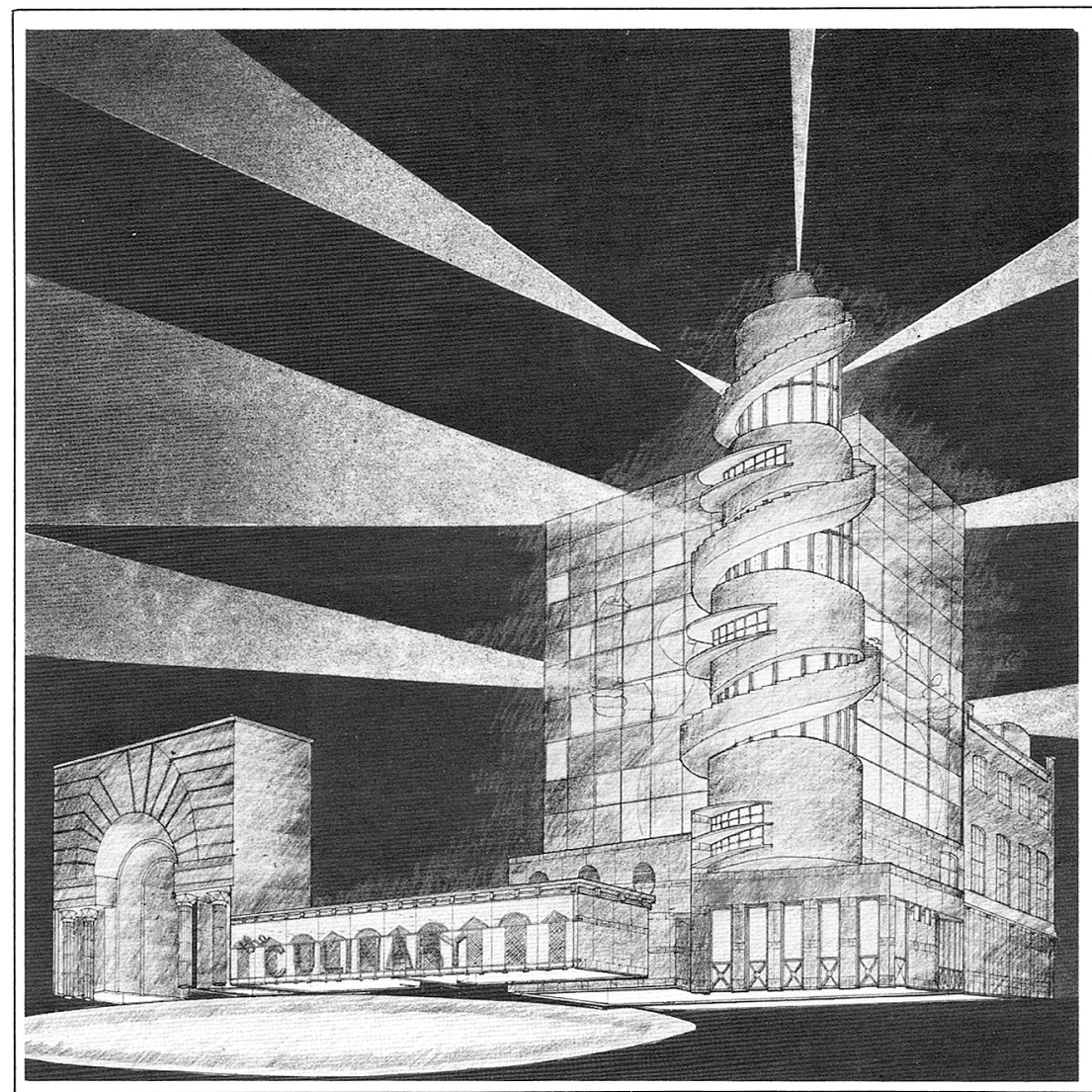

Joseph Biondo 